\title{
PENGARUH KONSEP TRI HITA KARANA TERHADAP PRAKTEK AKUNTANSI (PENGELOLAAN ASET) DI DESA TENGANAN
}

\author{
Putu Deby Purnamasari, Ni Gusti Nyoman Aprianti, Ni Luh Winda Rini, Kadek \\ Wahyu Dharma Laksana, Putu Ngurah Surya Widiantara, Desak Putu Mery \\ Astuti \\ Jurusan Akuntansi, Universitas Pendidikan Ganesha, Singaraja, Bali Indonesia
}

\begin{abstract}
Abstrak
Penelitian ini bertujuan untuk mengetahui bagaimana pengaruh budaya lokal Bali terhadap praktik akuntansi di Desa tenganan. Dengan melakukan sebuah penelitian dan membuat pembahasan dengan judul "Pengaruh Konsep Tri Hita Karana terhadap Praktek Akuntansi (Pengelolaan Aset Desa) di Desa Tenganan". Dari hasil penelitian Pemerintahan di Desa Tengan dibagi ke dalam Desa Ada dan Desa Dinas. Pemerintahan di desa dinas Tenganan didasarkan atas Undang-Undang yang berlaku dan pemerintahan desa adat tenganan berdasarkan atas awig-awig yang berlaku. Pemeritahan desa adat harus dipisahkan dari desa dinas.Jika dilihat dari desa dinas tidak ada yang berbeda antara praktik akuntansi dari Desa Tenganan dengan desa lainnya, Namun jika ditijau dari aspek adat maka Desa Tenganan memiliki perbedaan dalam hal Pengelolaan Aset Desa. Pengelolaan Aset di desa Tenganan didasarka pada awig -awig yang ada yang berlandaskan Konsep Tri Hita Karana. Aset utama dari Desa Tenganan berupa Tanah dan tanah desa adat di Tenganan dikelola dengan sistem Tika.
\end{abstract}

Kata kunci: Akuntansi, Tri Hita Karana, Pengelolaan

\begin{abstract}
This study aims to determine how the influence of Balinese local culture on accounting practices in the village of tenganan. By conducting a research and discussing with the title "The Effect of the Tri Hita Karana Concept on Accounting Practices (Village Asset Management) in Tenganan Village". From the results of Government research in the village of Tengan divided into Desa Ada and Desa Dinas. The administration in the Tenganan official village is based on the applicable laws and the tenganan traditional village government is based on the applicable awig-awig. The customary village government must be separated from the official village. If viewed from the official village, there is no difference between the accounting practices of Tenganan Village and other villages. However, if examined from the traditional aspect, Tenganan Village has a difference in terms of Village Asset Management. Asset Management in the village of Tenganan is based on the existing awig-awig based on the Tri Hita Karana Concept. The main assets of Tenganan Village in the form of Land and traditional village land in Tenganan are managed by the Tika system.
\end{abstract}

\section{Keywords : Accounting, Tri Hita Karana, Management}

\section{Pendahuluan}

Budaya atau Kebudayaan berasal dari bahasa sansekerta yaitu "buddayah", yang merupakan bentuk jamak dari "buddhi" (budi atau akal) jadi kebudayaan dapat diartikan sebagai hal-hal yang berkaitan dengan budi atau akal manusia. Secara umum kebudayaan merupakan hasil cipta, rasa serta karsa manusia dalam memenuhi kebutuhan hidupnya yang kompleks yang meliputi pengetahuan, kepercayaan, seni, susila, hukum kebiasaan serta tiap-tiap kecakapan serta rutinitas. Kebudayaan juga dapat diartikan sebagai keseluruhan manusia dari tingkah laku serta hasil yang perlu didapatkannya dengan belajar serta semuanya tersusun dalam kehidupan seseorang (koentjaraningrat). Jadi, budaya merupakan hasil cipta, rasa dan karsa manusia yang didapat dari sebuah kebiasaan suatu masyarakat itu sendiri yang nantinya digunakan sebagai pedoman dalam kehidupan sehari-hari. Sehingga kebudayaan dapat dikatakan sebagai pengatur hubungan manusia di dalam masyarakat. 
Dalam mengatur hubungan antar manusia kebudayaan dinamakan pula struktur normatif yaitu garis-garis-garis atau petunjuk dalam hidup yang artinya kebudayaan adalah suatu garis-garis pokok tentang perilaku yang menetapkan peraturan-peraturan mengenai apa yang seharusnya dilakukan dan apa yang dilarang dan lain-lain (Marpuah,2007). Kaidah-kaidah kebudayaan berarti peraturan tentang tingkahlaku atau tindakan yang harus dilakukan dalam suatu keadaan tertentu. Kaidah-kaidah kebudayaan mencangkup peraturan-peraturan yang mencangkup bidang yang sangat luas. Kaidah-kaidah kebudayaan dinamakan juga aturan moralitas, yaitu sistem nilai bagaimana seseorang harus hidup secara baik sebagai manusia. Sistem nilai mengandung ajaran yang berbentuk petuahpetuah, nasehat, wejangan, peraturan, perintah dan semacamnya yang diwariskan secara turun-temurun melalui agama atau kebudayaan . Penamaan dari aturan moralitas ini dikenal sebagai kearifan lokal atau budaya lokal. Setiap kelompok masyarakat memiliki kearifan atau budaya lokal yang berbeda-beda bergantung pada peraturan apa yang diwariskan oleh pendahulu kelompok masyarakat tersebut. Pada umumnya budaya pada suatu masyarakat dipengaruhi oleh kultur kelompok masyarakat itu sendiri termasuk kebiasaan dan juga pola perilaku masyarakat tersebut.

Seperti yang dikatakan sebelumnya bahwa setiap masyarakt memiliki budaya atau adata yang berbeda. Dalam setiap kelompok masyarakat, suku maupun bangsa dipastikan memiliki budaya tersendiri. Demikian pula halnya dengan kebudayaan yang ada pada daerah Bali. Adat dan Kebudayaan masyarakat Bali Bali sangat erat kaitannya dengan agama dan kehidupan religius masyarakat hindu. Keduanya telah memiliki akar sejarah yang demikian panjang dan mencerminkan konfigurasi ekspresif dengan dominasi nilai dan filosofi nilai religius agama Hindu. Dalam konfigurasi ini tertuang aspek berupa esensi keagamaan , pola kehidupan, lembaga kemasyarakatan, maupun kesenian yang berada di daerah Bali. Meskipun memiliki budaya tersendiri namun sebagai masyarakat atau bagian dari negara Indonesia masyarakat di Bali masih mengikuti undang- undang yang diterapkan di Indonesia. Seperti halnya dalam pemerintahan, di Bali terdapat pemerintah provinsi, Kabupaten/ kota, kecamatan dan Desa dan dalam menjalankan pemerintahaannya diterapkan otonomi daerah yang diatur dalam Undang-Undang nomor 32 tahun 2004.

Desa merupakan pembagian wilayah administratif di Indonesia di bawah kecamatan yang dipimpin oleh Kepala Desa. Dalam masyarakat Bali setiap desa yang ada mengikuti segala peraturan yang ditetapkan oleh pemerintah berdasarkan Undang-Undang termasuk juga dala pengelolaan dana ataupun aset desa (praktik akuntansinya). Namun, selain mengikuti undang-undang suatu desa juga mengikuti budaya yang ada dalam melaksanakan pemerintahannya yang dikenal dengan istilah "awig-awig desa". hal ini mengakibatkan pemerintahan untuk beberapa desa di Bali dapat digolongkan menjadi desa adat dan juga desa dinas. Desa adat menjalankan pemerintahan berdasarkan awig-awig desa sedangkan desa dinas menjalankan pemerintahan berdasarkan Undang-Undang. Setiap desa yang ada berkewajiban untuk menyelenggarakan akuntansi untuk mendukung proses akuntabilitas pengelolaan keuangannya kepada publik. Dasar atau standar yang digunakan dalam akuntansi desa adalah Standar Akuntansi pemerintahan (SAP). Dalam suatu desa adat yang ada di Bali pemerintahan akan mengikuti awig-awig yang dibuat oleh para pendahulunya (leluhur) sehingga terkadang di beberapa desa yang budayanya masih kental praktik akuntansinya dipengaruhi oleh kebudayaan atau awig-awig yang ada.

Dalam kelompok masyarakat Bali terdapat jenis kelompok masyarakat yang budaya Balinya masih sangat kental yang berdiam dalam satu tempat tinggal disebut Desa Bali Aga . Desa Bali Aga adalah desa yang mempertahankan aturan adat desa yang turun temurun. Salah satu desa Bali Aga yang ada di Bali adalah Desa Tenganan. Desa Tenganan merupakan salah satu Desa Bali Aga yang masih sangat mempertahankan keaslian dari budaya lokal Bali sehingga desa ini kerapkali menjadi ikon dalam perbincangan mengenai kebudayaan masyarakat Bali Aga (Bali asli). Desa Tenganan menjadi desa yang sangat menarik karena memiliki keunikan tersendiri . Keunikan desa ini adalah tidak mengenal istilah kasta atau dikatakan masyarakat tanpa kelas. Nenek moyang mereka menganut kepercayaan Dewa Indra yang dipengaruhi oleh Majapahit dan Hindu. Di desa ini memiliki awig-awig tersendiri yang mengatur tentang aset Desa Tenganan, salah satunya untuk aset 
tanah. Hal ini megakibatkan tanah di desa ini adalah tanah milik desa, mulai dari pemukiman, hutan, kebun dan sawah. Status kepemilikan tanah adalah milik bersama (komunal). Kepemilikan pribadi dilarang di desa ini. Semua lahan yang ada digunakan untuk kepentingan bersama dan dikelola masyarakat dan juga hukum adat yang masih kental. Masyarakat Desa Tenganan hanya boleh menikah dengan satu desa mereka, karena kalau mereka menikah dengan orang di luar desa mereka maka akan dikenakan sanksi berupa hukum adat. Karena keunikan inilah Desa Tenganan layak untuk dijadikan ikon dari desa Bali Aga (Bali asli) yang masih mempertahankan kearifan budaya-budaya lokal di dalam kehidupan sehari-hari.

Sebagaimana yang dikatakan sebelumnya budaya lokal Bali sangat identik dengan budaya religius mayoritas masyarakat Bali yaitu Agama Hindu. Hal ini mengakibatkan aturan-aturan dan pola kehidupan masyarakat Bali identik dengan ajaran Agama Hindu. Ada banyak sekali Filsafat Hindu yang dapat dijadikan pedoman di dalam melaksanakan kehidupan sehari-hari diantaranya Tri Kaya Parisudha , Arthasastra, konsep Tat Twam Asi, konsep Tri Hita karana dan masih banyak lagi konsep lain yang berumber dari filsafat hindu . Salah satu Konsep yang paling dikenal adalah konsep Tri Hita Karana. Tri Hita Karana berasal dari kata "Tri" yang berarti tiga, "Hita" yang berarti kebahagiaan dan dan "karana" berarti penyebab jadi Tri Hita Karana berarti "Tiga penyebab terciptanya kebahagiaan" (Wikipedia Bahasa Indonesia). Tri Hita karana terdiri dari Prahyangan (Hubungan harmonis antara manusia dengan Tuhan), Pawongan (Hubungan harmonis antara manusia dengan manusia lain) dan Palemahan (Hubungan harmonis antara manusia dengan alam atau lingkungan). Konsep Tri Hita Karana ini merupakan filsafat yang dapat melestarikan keanekaragaman budaya dan lingkungan di tengah pengaruh globalisasi. Masyarakat Desa Tenganan sendiri di dalam menjalankan Dharma Agama dan Darma Negara berdasarkan pada konsep Tri Hita Karana. Dharma agama adalah kewajiban menjalankan ajaran agama, sedangkan Dharma Negara adalah kewajiban dalam menjalankan aturan-aturan yang telah ditetapkan oleh Negara. Sekaligus Tri Hita Karana ini dijadikan dasar dalam penyusunan awig-awig. Karena itulah kehidupan masyarakat Desa Tenganan didasarkan pada konsep Tri Hita Karana yang diatur dalam hukum adat yang disebut awig-awig yang ditulis pada abad ke 11 dan diperbaharui pada tahun 1942. Di dalam awig-awig inilah diatur bagaimana sistem pemerintahan desa adat, pola perilaku, pola kehidupan, dan termasuk juga pengelolaan kekayaan desa. Awig-awig merupakan pedoman dasar dari desa adat untuk mengatur jalannya pemerintahan desa adat. Dengan kata lain awig-awig merupakan bagian dari sistem hukum dalam adat yang bercorak unik karena sifatnya magis religius. Sifat inilah yang membuat masyarakat menaatinya karena merasakannya sebagai kewajiban moral. Bagi masyarakat disana menaati awig-awig adalah suatu kewajiban mutlak.

Bedasarkan uraian di atas maka penulis ingin memaparkan bagaimana pengaruh budaya lokal Bali terhadap praktik akuntansi di Desa tenganan. Dengan melakukan sebuah penelitian dan membuat pembahasan dengan judul "Pengaruh Konsep Tri Hita Karana terhadap Praktek Akuntansi (Pengelolaan Aset Desa) di Desa Tenganan". Berdasarkan latar belakang diatas, masalah yang dapat dirumuskan adalah Apa yang membedakan praktik akuntansi di Desa Tenganan dengan desa lain di Bali, Bagaimana Konsep Tri Hita Karana dapat berpengaruh terhadap pengeloalaan aset di Desa Tenganan, Bagaimana perbandingan pengelolaan keuangan antara Desa Adat dan Desa Dinas di Desa Tenganan.

\section{Pembahasan}

\subsection{Gambaran Umum}

a. Sejarah Desa Tenganan

Desa Tenganan adalah salah satu desa yang masyarakatnya berjuang mempertahankan identitas yang mereka banggakan sebagai orang Bali asli. Ciri khas Desa Tenganan adalah kain tenun ikat yang disebut Kain Gringsing. Karena itu, nama desa ini lebih dikenal dengan Desa Tenganan Pegringsingan. Ini untuk membedakannya dengan Desa Tenganan Dauh Tukad atau pun Tenganan sebagai desa dinas.

Menurut cerita masyarakat setempat, Tenganan berasal dari kata "ngatengahang" (bergerak ke tengah). Ini berkaitan dengan cerita berpindahnya warga Tenganan dari pesisir 
Pantai Ujung mencari tempat lebih ke tengah. Kata Pegringsingan diambil dari kata "gringsing" yang terdiri dari kata "gring" dan "sing". Gring berarti sakit dan sing berarti tidak. Masyarakat Bali Aga percaya gringsing memiliki kekuatan magis yang melindungi mereka dari sakit dan kekuatan jahat. Jadi gringsing berarti tidak sakit, selain itu gringsing merupakan kain tenun ikat ganda khas Tenganan, sehingga diyakini orang yang memakai kain Gringsing dipercaya dapat terhindar dari penyakit dan dapat terhindar dari bahaya.

Terdapat kisah mitologi dari Desa Tenganan Pegringsingan, kisahnya bermula dari kemenangan Dewa Indra atas peperangan dengan Raja Mayadenawa yang otoriter. Setelah perang berakhir masyarakat Desa Tenganan Pegringsingan mengadakan upacara penyucian dengan kurban seekor kuda. Terpilihkan Oncesrawa, kuda milik Dewa Indra sebagai bakal kurbannya. Kuda Onceswara ini adalah kuda sakti, memiliki bulu putih dengan ekor warna hitam yang panjangnya sampai menyentuh tanah. Kuda ini diyakini muncul dari laut, melarikan diri ketika mengetahui bahwa dirinya akan dijadikan kurban. Dewa Indra kemudian menugaskan Wong Peneges, prajurit Kerajaan Bedahulu, untuk mencari Kuda Oncesrawa.

Orang-orang Paneges dibagi dalam dua kelompok, yaitu: Kelompok pertama mencari ke arah Barat dan kelompok kedua mencari ke arah Timur. Kelompok pertama tidak menemukan jejak kuda kurban, sedangkan kelompok kedua berhasil menemukan kuda tersebut dalam keadaan mati pada suatu tempat di lereng bukit, yang sekarang disebut Bukit Kaja 'Bukit Utara', yang sekarang dikenal dengan Desa Tenganan Pegringsingan. Hal itu segera diketahui oleh Dewa Indra. Selanjutnya, Beliau bersabda untuk memberikan anugerah berupa tanah seluas bau bangkai tercium. Wong Peneges rupanya 'cerdik', mereka memotong-motong bangkai kuda itu dan membawanya sejauh yang mereka inginkan. Dewa Indra mengetahui hal itu, lalu turunlah Dewa Indra sembari melambaikan tangan, sebagai tanda bahwa wilayah yang mereka inginkan sudah cukup. Wilayah itulah yang sekarang disebut sebagai Tenganan Pegringsingan.

b. Kependudukan

Masyarakat desa adat Tenganan Pegringsingan secara umum dibedakan ke dalam dua kelompok besar, yaitu: 1) masyarakat desa adat Tenganan Pegringsingan asli yakni warga keturunan orang-orang Paneges yang pertama kali menempati wilayah Tenganan Pegringsingan dan berdaulat secara adat atas wilayah tersebut serta merupakan penduduk asli yang bermukim di Banjar Tengah dan Banjar Kauh, (2) orang-orang pendatang adalah orang-orang yang sengaja datang dengan kepentingan untuk tinggal di Desa Adat Tenganan dengan alas an ditugaskan oleh pemerintah atau mencari pekerjaan. Biasanya pendatang yang diundang ke desa ini adalah pada golongan pande, pasek, dan dukuh, sedangkan pendatang yang datang atas keinginan sendiri disebut Wong Angendong Jenek. Keduanya bermukim di Banjar Pande.

Masyarakat asli Desa Adat Tenganan Pegringsingan dibedakan lagi ke dalam beberapa kelompok: (1) kelompok masyarakat yang belum menikah dan (2) kelompok masyarakat yang sudah menikah. Kedua kelompok ini dibagi ke dalam sub kelompok, bagi masyarakat yang belum menikah dibedakan menurut jenis kelamin, yaitu: (a) Krama Teruna untuk laki-laki yang sudah remaja dan (b) Krama Deha untuk para gadis yang sudah remaja. Baik krama teruna dan karma deha, secara tersendiri membagi diri menjadi tiga sub kelompok, sehingga jumlah sub kelompok tersebut berjumlah enam kelompok, sebagai berikut: 1) Teruna Petemu Kaja; 2) Teruna Petemu Tengah; 3) Teruna Petemu Kelod; serta 4) Deha Wayah; 5) Deha Nengah; 6) Deha Nyoman. Pengelompokan tersebut berdasarkan kelompok yang ditempati oleh ayah dan atau ibu yang bersangkutan. Sedangkan penduduk asli Desa Adat Tenganan Pegringsingan yang sudah menikah dibagi ke dalam tiga kelompok, yaitu 1) Krama Desa; 2) Krama Gumi Pulangan; 3) Krama Gumi (Unggu).

c. Kondisi Sosial Ekonomi Masyarakat

Desa Tenganan terletak ditengah-tengah di antara perbukitan yang ada di kecamatan Manggis, Karangasem, Bali. Walaupun sudah memasuki zaman modern, Penduduk Tenganan masih menggunakan sistem barter dalam kehidupan sehari-harinya.

Masyarakat Desa Adat Tenganan memiliki beragam mata pencaharian salah satunya yang sangat dikenal oleh masyarakat luas adalah sebagai penenun kain Geringsing. Selain 
sebagai penenun kain, masyarakat dari Desa Tenganan ini juga ada yang bekerja sebagai pengerajin lontar ataupun kerajinan tangan lainnya. Dilihat dari kondisi geografis, masyarakat Desa Adat Tenganan Pegringsingan mengelola sumber daya alam yang dimiliki sesuai dengan fungsi lahan yang tersedia, seperti lahan persawahan, hutan, pura, kolam, tegalan sehingga masyarakatnya juga bermata pencaharian sebagai petani. Petani disini adalah petani pemilik bukan sekedar petani penggarap.

\section{d. Adat Istiadat}

Keseharian kehidupan di desa ini masih diatur oleh hukum adat yang disebut awigawig. Hukum tersebut ditulis pada abad ke-11 dan diperbaharui pada tahun 1842. Rumah adat Tenganan dibangun dari campuran batu merah, batu sungai, dan tanah. Sementara atapnya terbuat dari tumpukan daun rumbi. Rumah adat yang ada memiliki bentuk dan ukuran yang relatif sama, dengan ciri khas berupa pintu masuk yang lebarnya hanya berukuran satu orang dewasa. Ciri lain adalah bagian atas pintu terlihat menyatu dengan atap rumah.

Penduduk desa ini memiliki tradisi unik dalam merekrut calon pemimpin desa, salah satunya melalui prosesi adat mesabat-sabatan biu (perang buah pisang). Calon prajuru desa dididik menurut adat setempat sejak kecil atau secara bertahap dan tradisi adat tersebut merupakan semacam tes psikologis bagi calon pemimpin desa. Pada tanggal yang telah ditentukan menurut sistem penanggalan setempat (sekitar Juli) akan digelar ngusaba sambah dengan tradisi unik berupa mageret pandan (perang pandan). Dalam acara tersebut, dua pasang pemuda desa akan bertarung di atas panggung dengan saling sayat menggunakan duri-duri pandan. Walaupun akan menimbulkan luka, mereka memiliki obat antiseptik dari bahan umbi-umbian yang akan diolesi pada semua luka hingga mengering dan sembuh dalam beberapa hari. Tradisi tersebut untuk melanjutkan latihan perang rutin dan menciptakan warga dengan kondisi fisik serta mental yang kuat. Penduduk Tenganan telah dikenal sebagai penganut Hindu aliran Dewa Indra, yang dipercaya sebagai dewa perang. Masyarakat Tenganan mengajarkan dan memegang teguh konsep Tri Hita Karana (konsep dalam ajaran Hindu) dan mewujudkannya dalam kehidupan sehari-hari

\section{e. Struktur Pemerintahan}

Struktur pemerintahan desa dinas tenganan sama dengan desa-desa lainnya yang terdidi dari kepala desa, sekretaris desa, kaur (kepala urusan) atau kepala bagian dan juga kepala dinas atau banjar. Sedangkan Struktur pemerintahan desa adat bersifat kolektif, yang terdiri dari krama desa (klian adat), gumi pulangan dan gumi. Krama desa merupakan lembaga tertinggi secara adat di desa tenganan yang bertugas mengatur tata kehidupan warga masyarakat adat dalam bidang upacara, pembangunan dan pemerintahan. Sebagai sebuah kelembagaan sosial dan tradisional, krama desa berperan mengatur rumah tangganya sesuai kesepakatan. Dalam menjalankan tugasnya krama desa taat pada awigawig desa baik yang tertulis maupun yang tidak tertulis (dresta).

Adapun Struktur krama desa meliputi; pertama, Luanan yang memiliki fungsi sebagai penasehat,luanan ini diangkat dari nomor-nomor perkawinan 1 sampai dengan 5, mereka adalah orang-orang yang dituakan (penglingsir ). Luanan akan diminra hadir bila persiapan sudah selesai. Biasanya kehadiran 5 pasang suami-istri luanan itu disertai dengan 1 pasang De mangku; kedua, Bahan Roras, yang bertugas sebagai pelaksana pemerintahan. Bahan roras diangkat dari nomer (perwakilan) 6 sampai dengan 17 dan satu orang setiap bulan bertugas sebagai sekretaris. Bahan duluan, yaitu nomer 6 sampai dengan nomer 11 menjadi kepala(Klian) desa adat yang menjadi pelaksana pemerintahan harian, perencana, pelaksana pucuk pimpinan, 2 orang pasang sampai nomor 6 dan nomor 7 menjadi tamping takon dan bahan tebenan sebagai pembantu cadangan dalam klian desa. Dengan demikiana, untuk bahan roras terdapat 12 pasang perkawinan sampai 6 pasang perkawinan, 6 pasang bahan Duluan, 6 pasang bahan tebenan. Ketiga, Pengeluduan, mempunyai tugas sebagai juru arah atau administrasi, juru arah terdiri dari dua, yaitu, 1 tambalapu duluan nomor perkawinan 18-23 sebagai penggerak dalam semua kegiatan, 2 tambalapu tebenan nomor perkawinan 24-29 cadangan dan penggantinya kemudian.

Dengan adanya kekosongan jabatan ini kemudian diisi oleh anggota krama desa yang berada persis dibawahnya dan beralih ke atas satu tingkat. Kondidi ini secara otomatis diikuti 
oleh bergesernya semua anggota krama desa yang berafa dibawah anggota yang naik tersebut. Pola pergeseran semua anggota sudah disepakati sebagai ketentuan oleh para krama desa di desda tenganan. Berlangsungnya perpindahan kekuasaan ada yang terjadi pada tiap bulan sekali, yaitu pada saat pesangkepan pati panten untuk mengangkat seorang penyarikan (carik atau juru tulis ) dan empat orang tat usaha. Krama desa merupakan lembaga tertinggi secara adat yang mengatur tat kehidupan warga dalam bidang upacara, pembangunan dan pemerintahan adat. Adapun tugas-tugasnya meliputi; (1) melaksanakan awig-awig desa,(2) mengatur penyelenggaraan upacara keagamaan bagi desa adat, sesuai dengan sastra agama, (3) mengusahakan perdamaian dan meyelesaikan sengketa adat sebagai hakim desa,(4) mengembangkan kebudayaan di desa adat dalam upaya melestarikan kebudayaan daerah dalam rangka memperkaya kebudayaan nasional, (5) membina dan mengkordinasikan masyarakat desa guna meningkatkan kesadaran sosial dan semangat kegotong royongan, 6 mewakili desa adat dan bertindak atas nama dan untuk desa adat dalam segla perbuatan hukum di dalam dan di luar pengadilan, (7) mengurus dan mengelola harta dan pusaka desa adat, (8) mengatur, memelihara, memperbaiki, mengawasi keberadaan setiap bangunan, (9) mengatur pemanfaatan kekayaan dan uang kas desa.

\subsection{Perbedaan Praktik akuntansi di Desa Tenganan dengan desa lain di Bali.}

Praktik akuntansi desa erat kaitannyadengan cara pengelolaan dana desa. Pengelolaan dan pertanggungjawaban dana desa saat ini mulai diperhatikan sejak dikeluarkannya Undang-Undang Nomor 6 tahun 2014 tentang desa. Menurut pasal 71 ayat 1 UU Nomor 6 tahun 2014 dinyatakan bahwa keuangan desa adalah hak dan kewajiban Desa yang dapat dinilai dengan uang serta segala sesuatu berupa uang dan barang yang berhubungan dengan pelaksanaan hak dan kewajiban Desa. dan pada ayat(2) dinyatakan bahwa adanya hak dan kewajiban akan menimbulkan pendapatan, belanja, pembiayaan dan pengelolaan keuangan desa. Pasal 93 ayat (1) menyatakan bahwa pengelolaan keuangan desa meliputi :

1. Perencanaan, yang meliputi:

a. Rancangan Peraturan Desa tentang APBDes dibuat, disampaikan oleh Kepala Desa dan dibahas dengan Bdan Permusyawaratan Desa untuk disepakati paling lambat bulan oktober tahun mendatang.

b. Rancangan Peraturan Desa tentang APBDes yang telah disepakati disampaikan oleh Kepala Desa kepada Bupati atau Walikota melalui camat atau sebutan lain paling lambat tiga hari sejak disepakati untuk dievaluasi.

c. Bupati/Walikota melakukan evaluasi paling lama 20 (dua puluh)hari sejak diterimanya Rancangan Peraturan Desa tentang APBDes. Dalam hal Bupati / Walikota tidak melakukan evaluasi dalam batas waktu tersebut, maka Peratuan Desa berlaku dengan sendirinya.

d. Dalam hal ada koreksi yang disampaikan atau penyesuaian yang harus dilakukan dari hasil evaluasi tersebut, maka Kepala Desa harus melakukan penyempurnaan paling lambat 7 (tujuh) hari kerja sejak diterimanya hasil evaluasi.

e. Apabila hasil evaluasi tidak ditindaklanjuti oleh Kepala Desa dan Kepala Desa tetap menetapkan Rancangan Peraturan Kepala Desa tentang APBDesa menjadi Perauran Desa dengan keputusan Bupati atau Walikota. Dengan dilakukan pembatalan Peraturan desa tersebut sekaligus menyatakan berlakunya pagu APBDesa tahun anggaran sebelumnya. Dalam hal terjadi pemabatalan, Kepala Desa hanya dapat melakukan pengeluaran terhadap operasional penyelenggaraan Pemerintahan Desa.

f. Kepala Desa memberhentikan pelaksanaan Peraturan Desa paling lam 7 (Tujuh) hari kerja setelah pembatalan dan selanjutnya bersama BPD mencabut Peraturan Desa yang dimaksud.

g. Dalam Hal Bupati atau Walikota mendelegasikan evaluasi Rancangan Peraturan Desa tentang APBDesa kepada camat atau sebutan lain, maka langkah yang dilakukan adalah:

1) Camat menetapkan hasil evaluasi Rancangan APBDesa paling lama 20 (dua puluh) hari kerja sejak diterimanya Rancangan Peraturan Desa tentang APBDesa. 
2) Dalam hal camat tidak memberikan hasil evaluasi dalam batas waktu yang ditetapkan, Peraturan Desa tersebut berlaku dengan sendirinya.

3) Dalam hal ada koreksi yang disampaikan atau penyesuaian yang harus dilakukan ari hasil evaluasi tersebut, Kepala Desa melakukan penyempurnaan Paling lama 7(tujuh) hari kerja terhitung diterimanya evaluasi.

4) Apabila hasil evaluasi tidak ditindaklanjuti oleh Kepala Desa dan Kepala Desa tetap menetapkan Rancangan Peraturan Kepala Desa tentang APMBDesa menjadi Peraturan Desa, Camat menyampaikan usulan pembatalan Peraturan Desa kepad Bupati atau Walikota.

2. Pelaksanaan, yang meliputi:

a. Semua penerimaan dan pengeluaran desa dalam rangka pelaksanaan kewenangan desa dilakukan melalui Rekening Kas Desa.

b. Semua penerimaan dan pengeluaran desa harus didukung oleh bukti yang lengkap dan sah.

c. pemerintah desa dilarang melakukan pungutan sebagai penerimaan desa selain yang ditetapkan dalam peraturan desa.

d. Bendahara dapat menyimpan uang dalam Kas Desa pada jumlah tertentu dalam rnagaka memenuhi kebutuhan operasional pemerintah desa.

e. Pengeluaran desa yang mengakibatkan beban APBDesa tidak dapat dilakukan sebelum rancangan Peraturan Desa tentang APBDesa ditetapkan menjadi Peraturan Desa.

f. Pengeluaran desa untuk belanja pegawai yang bersifat mengikat danoperasional perkantoran yang ditetapkan dalam peraturan kepala desa tetap dapat dikeluarkan walaupun rancangan peraturan desa tentang APBDesa belum ditetapkan.

g. Pelaksanaan Kegiatan mengajukan pendanaan untuk melaksanakan kegiatan harus disertai dengan dokumen diantaranya RAB. Sebelum digunakan RAB tersebut diverifikasi oleh sekretaris desa dan disahkan oleh Kepala Desa.

h. Pelaksanaan Kegiatan pertanggungjawaban terhadap tindakan yang menyebabkan pengeluaran atas beban anggaran belanja kegiatan dengan mempergunakan Buku Pembantu Kas Kegiatan sebagai pertanggujawaban pelaksanaan kegiatan desa.

3. Penatausahaan, yang meliputi:

Bandahara desa wajib:

a. Melakukan pencatatan setiap penerimaan dan pengeluaran serta melakukan tutup buku setiap akhir bulan secara tertib. Penatausahaan penerimaan dan pengeluaran dilakukan menggunakan : Buku Kas Umum, Buku Kas Pembantu pajak dan Buku Bank.

b. Mempertanggungjawabkan uang melalui laporan pertanggungjawaban.

4. Pelaporan, yang meliputi:

a. Laporan semester pertama, berupa Laporan Realisasi pelaksanaan APBDesa , Semester Pertama.

b. Laporan semester akhir tahun, berupa Laporan Realisasi Pelaksanaan APBDesa Semester Akhir.

5. Pertanggungjawaban, yang meliputi:

Kepala Desa menyampaikan kepada Bupati/ Walikota setiap akhir tahun anggaran laporan yang meliputi:

a. Laporan Pertanggunjawaban Realisasi pelaksanaan APBDesa tahun anggaran berkenaan.

- Merupakan laporan yang tidak terpisahkan dari laporan penyelenggaraan Pemerinta Desa.

- Diinformasikan kepada masyarakat secara tertulis dengan media informasi yang muda diakses oleh masyarakat.

- disampaikan kepada Bupati/Walikota melalui Camat atau sebutan lain.

b. Laporan kekayaan milik desa per 31 Desember Tahun Anggaran berkenaan.

c. Laporan Program Pemerintah dan Pemerintah daerah yang masuk ke desa.

6. Pembinaan dan Pengawasan. 
a. Pemerintah Provinsi wajib membina dan mengawasi pemerian dan penyaluran Dana Desa , Alokasi Dana Desa, dan Bagi Hasil Pajak Dan Retribusi Daerah dari Kabupaten/Kota Kepada Desa.

b. Pemerintah Kabupaten/Kota wajib membina dan mengawasi pelaksanaan pengelolaan keuangan Desa.

Peraturan ini sudah menjelaskan bagaimana praktik akuntansi pengelolaan dana desa pada umumnya dan semua desa yang ada di Indonesia termasuk juga di Bali harus mengikuti aturan praktik tersebut.

Bali merupakan provisi atau pulau yang memiliki kebudayaan yang unik dan beberapa desa masih mempertahankan kebudayaan atau kearifan lokal khas Bali seperti halnya Desa Tenganan. Kearifan lokal khas Bali ini mengakibatkan pemerintahan di Desa tenganan mengandung sistem dualisme dimana terdapat dua sisi pemerintahan yaitu desa adat dan desa dinas. Untuk pengelolaan keuangan atau praktik akuntansi di Desa Tenganan juga menjadi Praktik Akuntansi untuk di Desa Dinas Tenganan dan Praktik Akuntansi di Desa Adat tenganan. Untuk pengelolaan atau praktik akuntansi di Desa Dinas Tenganan hampir sama dengan desa-desa pada umumnya karena mengacu kepada Undang-Undang yang berlaku baik dalam perencanaan, pelaksanaan, penatausahaan, pelaporan, pertanggungjawaban, ataupun pembinaan dan pengawasan. Pencatatan di desa ini masih sangat sederhana, hanya meliputi pemasukan dan pengeluaran secara historis. Yang berbeda antara praktik akuntansi di Desa Tenganan dengan desa lainnya terdapat pada Desa Adat-nya khususnya pada pengelolaan aset desa berupa tanah. Seperti yang dikatakan sebelumnya Tanah Adat Desa Tenganan mempunyai luas sekitar 917,2 ha yang terdiri dari 255 ha sawah dan 583 ha yang terdiri dari tegalan dan hutan. dan seperti yang kita ketahui pula hal ini menyebabkan mayoritas masyarakat di Desa Tenganan adalah petani. Pengelolaan aset tanah ini dikelola sesuai dengan awig-awig yang berlaku di desa tersebut. Setiap tanah yang ada di Desa Tenganan tidak boleh dijual atau disewakan kepada pihak luar apapun alasannya. Tanah pribadi milik warga desa diwariskan kepada semua anak-anaknya secara merata baik itu laki-laki ataupun perempuan. Namun, apabila ada anak perempuan menikah dengan orang dari luar Desa Tenganan maka hak atas warisan tanah tidak diberikan, ini untuk mendukung awig-awig agar tanah yang ada di desa tidak dimiliki oleh orang yang bukan warga Desa Tenganan. Selain itu di dalam awig-awig desa adat juga dinyatakan tentang Hak ngerampag yang dimiliki oleh desa adat, yaitu hak mengambil hasil bumi di tanah milik pribadi. Dengan adanya hak ini dari total luas tanah yang dimiliki oleh adat, organisasi, pribadi atau kelompok, jika desa adat membutuhkan kayu, buah-buahan atau hasil bumi lainnya maka mereka (pemilik tanah) wajib untuk menyerahkannya. Pohonpohon yang ada di desa Tenganan juga tidak boleh ditebang dengan sembarangan, pohon hanya boleh ditebang jika diperlukan untuk keperluan desa adat ataupun untuk membangun rumah. Jika ada pohon-pohon yang tumbang maka kayunya secara otomatis akan menjadi milik desa adat yang nantinya digunakan untuk membuat atau memperbaiki fasilitas umum, hal ini berlaku untuk seluruh pohon yang ada termasuk pohon yang ada pada tanah miliki pribadi. Pohon yang boleh ditebangpun haruslah pohon yang sudah tua ataupun mati. Selain itu semua buah atau hasil lainnya yang ada di seluruh Desa Tenganan menjadi milik desa adat dan seluruh warga yang ada diperbolehkan untuk mengambil buah yang jatuh setelah masak di pohonnya. Hal ini sudah menjadi aturan dalam awig-awig Desa Tenganan sehingga apabila melakukan pelanggaran akan dikenai sanksi adat berupa teguran, dikucilkan bahkan dikeluarkan dari desa. Untuk Tanah desa sendiri dikelola oleh krama desa. Desa adat memiliki 6 subak. Subak adalah organisasi kemasyarakatan yang khusus mengatur sistem pengairan sawah yang digunakan dalam cocok tanam padi di Bali. Sawah yang ada pada keenam subak ini digarap oleh penyakap (penggarap sawah) yang mendapatkan bagi hasil sesuai dengan kesepakatan dengan desa adat. Desa tenganan memiliki disini dikelola dengan sistem Tika. Berdasarkan sistem Tika yang diatur dalam awig-awig ini setiap hasil yang diperoleh dari tanah desa akan digunakan untuk kesejahteraan masyarakat desa. Untuk panen pertama dan kedua, hasil panennya akan dijual dengan harga yang sesuai, kemudian hasil dari penjualan ini akan disimpan di kas desa adat untuk nantinya digunakan dalam pembangunan seperti perbaikan tempat suci 
desa dan perbaikan fasilitas umum ataupun upacara-upacara serta tradisi adat yang akan dilakukan di Desa Tenganan seperti tradisi Perang Pandan yang menjadi ikon Desa Tenganan dan hanya ada di Tenganan. Untuk panen selanjutnya hasilnya akan dibagikan kepada krama desa sesuai dengan jabatan yang dimiliki dalam desa adat. kira-kira setiap krama desa mendapatkan $50 \mathrm{~kg}$ per bulan, kecuali bulan pertama mendapat 1 karung dan pada bulan ke 5 mendapat 2 karung.

\subsection{Pengaruh Konsep Tri Hita Karana terhadap Pengelolaan Aset di Desa Tenganan}

Kebudayaan adalah segala hal yang dimiliki oleh manusia yang hanya diperolehnya dengan belajar dan menggunakan akalnya (Koentjaraningrat, 2005:11), sedangkan Dharmayuda (1996:29) menyatakan bahwa kebudayaan tercipta melalui pengembangan kemampuan (daya) dari budi (idep), juga dinyatakan bahwa karena hakekat kemanusiaannya dan setelah kebudayaan tercipta, dengan itu kemudian manusia melestarikan kemanusiaannya.

Kebudayaan mesti dilestarikan karena memiliki unsur-unsur yang bersifat universal seperti bahasa, sistem teknologi, sistem ekonomi, organisasi sosial, sistem pengetahuan, kesenian, dan sistem religi (Koentjaraningrat, 2005:11). Unsur-unsur kebudayaan di Bali yang bersifat universal dan dinamis adalah THK (Tri Hita Karana). Tri Hita Karana diartikan sebagai tiga buah hubungan antara manusia dengan Tuhan, hubungan antara manusia dengan lingkungan, dan hubungan manusia dengan manusia. Konsep Tri Hita Karana dilihat dari setiap masyarakat Bali karena merupakan suatu budaya yang diwarisi secara turun-temurun.

Konsep Tri Hita Karana menekankan perlunya menyeimbangkan kinerja budaya dan kinerja bisnis dalam setiap kegiatan perekonomian. Dalam penelitian ini kegiatan perekonomian yang akan dibahas yaitu kegiatan perekonomian yang dikaitkan dengan proses pengelolaan aset oleh masyarakat di Desa Tenganan. Penelitian ini menemukan bahwa nilai-nilai yang terkandung di dalam kultur THK terbukti mempengaruhi secara signifikan dalam mengelola aset.

Kemampuan dalam mengelola aset di desa Tenganan di dapat melalui pengalaman masa lalu dan pekerjaan yang dilakukan saat ini. Konsep Tri Hita Karana memuat nilai-nilai pentingnya keselarasan dalam berperilaku dalam menjalani hidup dan kehidupan dan pekerjaan. Berperilaku tidak terlepas dari keyakinan diri yang merupakan kebutuhan psikologis dan menjadi kebutuhan ekonomi untuk penyesuaian diri.

Penelitian ini mengungkapkan bahwa nilai-nilai falsafah Tri Hita Karana membentuk sikap mental serta perilaku pengelola aset yang telah memainkan peran dalam pertumbuhan dan Kinerja. Falsafah Tri Hita Karana selain memainkan peran dalam pertumbuhan dan kinerja juga berperan dalam pengelolaan dan pelestarian. Penelitian ini menunjukkan bahwa Tri Hita Karana peranannya sangat penting dalam pengelolaan aset di desa Tenganan. Dalam mengelola aset dibutuh sikap yang jujur, adil, transparansi. Untuk membentuk sikap budaya THK yang seperti itu tidaklah mudah, memerlukan suatu keadaan yang seimbang dan harmoni antara kegiatan dan lingkungan. Keadaan ini memerlukan kedamaian dan kesejahteraan yang merupakan dasar keseimbangan dan keharmonisan yang diinginkan dengan memadukan semua komponen dan unsur-unsur budaya yang dimiliki.

Pengelolaan aset di Desa tenganan yang berdasarkan konsep Tri Hita Karana untuk mencapai kesejahteraan sekala dan niskala dalam penelitian ini menemukan bahwa program pendidikan yang dapat memberdayakan dan ikut berpartisipasi mewujudkan nilainilai Tri Hita Karana yakni pengetahuan sosial budaya dan agama Hindu, pemahaman konseptual ideologi Tri Hita Karana. Tri Hita Karana yang seimbang dapat dicirikan pada saat terjadinya hubungan yang saling mengisi dan memberi antara satu dengan yang lainnya. Hubungan ini terjadi pada agama dan ilmu karena ada pepatah yang mengatakan bahwa agama tanpa ilmu lumpuh, ilmu tanpa agama buta dan kedua hubungan ini didapat melalui pendidikan. Tri Hita Karana terdiri dari 3 bagian yaitu :

1. Pariyangan yang artinya hubungan antara manusia dengan tuhan

2. Pawongan yang artinya hubungan manusia dengan manusia

3. Palemahan yang artinya hubungan manusia dengan lingkungan 
Masyarakat di desa Tenganan didalam mengelola keuangan negara menggunakan konsep Tri Hita Karana. Artinya masyarakat Tenganan didalam mengelola aset yang dimilikinya berlandaskan atas Tri Hita Karana. Dalam penelitian ini telah ditemukan pengaplikasian konsep Tri Hita Karana sebagai berikut :

1. Parahyangan

Masyarakat Tenganan di dalam mengeklola asetnya terutama di dalam penyetoran dana atas pengelolaan asetnya tidak berani untuk melakukan penyelewenganpenyelewengan. Penyelewengan yang dimaksudkan disini ialah bahwa masyarakat Tenganan setelah mengelola asetnya yaitu berupa hasil sawah tidak berani melakukan kecurangan seperti korupsi hasil sawah. Masyarakat Tenganan memiliki sifat vertikal, artinya masyarakat Tenganan sangat meyakini bahwa apabila di dalam mengelola aset melakukan kecurangan akan mendapatkan karma yang sangat fatal. Keyakinan itu bukan hanya sebatas keyakinan. Keyakinan masyarakat Tenganan muncul karena konon katanya dlu pernah terjadi seorang pimpinan melakukan kecurangan di dalam pengelolaan aset dan pada akhirnya kehidupn seorang pemimpin tersebut tidaklah mujur. Oleh karena itu masyarakat Tenganan sangat takut untuk melakukan kecurangan. Dalam hal ini juga, setelah mengelola aset , masyarakat Tenganan tidak melakukan pelaporan kepada seluruh warga , melainkan hanya mencatat hasil akhir dari pengelolaan aset dan pada akhir tahun seluruh catatan tersebut akan dilebur. Ini menandakan transparansi masyarakat Tenganan tidaklah ada.

2. Pawongan

Pawongan memiliki pengertian hubungan manusia dengan manusia. Masyarakat Tenganan menerapkan konsep pawongan saat mengelola aset. Masyarakat Tenganan saling bekerjasama untuk mengelola aset agar aset yang dimiliki tidak berkurang . Usaha yang dilakukan masyarakat Tenganan untuk mempertahankan asetnya yaitu dengan cara tidak menjual asetnya yaitu berupa tanah. Masyarakat Tenganan selalu berusaha mempertahankan titipan nenek moyangnya, dan apabila masyarakat Tenganan memang sangat membutuhkan dana untuk memenuhi kebutuhannya usaha yang dilakukan yaitu dengan menjual tanahnya tapi hanya dijual ke warga yang tinggal di Tenganan dan tidak boleh dijual ke luar.

3. Palemahan

Palemahan merupakan hubungan antara manusia dengan lingkungan. MasyarakatTenganan selalu berusaha untuk mempertahankan asetnya. Terbukti dari pemeliharaan pohon di kebun. Masyarakat Tenganan tidak diperbolehkan melakukan penebangan pohon apabila pohon tersebut tidak mati sendiri. Tetapi apabila akan melakukan penebangan pohon dengan alasan tertentu harus melapor ke pimpinan dan harus mendapat persetujuan dari masyarakat Tenganan yang lainnya sehingga penebangan baru bisa dilakukan apabila dipersetujui.

\subsection{Perbandingan Pengelolaan keuangan antara desa adat dan desa dinas di Desa Tenganan.}

Menurut Peraturan Pemerintah nomor 72 tahun 2005 dalam pasal 1 ayat 6, Pemerintahan desa adalah penyelenggaraan urusan pemerintahan oleh Pemerintah Desa dan Badan Permusyawaratan Desa dalam mengatur dan mengurus kepentingan masyarakat setempat berdasarkan asal-usul dan adat-istiadat setempat yang diakui dan dihormati dalam sistem Pemerintahan Negara Kesatuan Republik Indonesia. Di desa-desa yang ada di Bali dibagi ke dalam 2 jenis pemerintahan yaitu pada desa dinas dan desa adat begitu pula dengan Desa Tenganan. Desa Dinas Tenganan dan desa adat yang ada di Tenganan memiliki aturan tersendiri di dalam penyelenggaraan pemerintahannya. Pemerintaan desa dinas tenganan dipimpin oleh seorang Kepada Desa dan dibantu oleh seluruh jajarannya. Sedangkan desa adat dipimpin oleh klian adat yang dibantu oleh karma desa. Setiap warga yang ada di Desa Tenganan merupakan bagian dari desa dinas tenganan dan sekaligus juga merupakan bagian dari desa adat tenganan. Oleh karena itu warga harus bisa memposisikan diri, apabila menyangkut dengan urusan dinas maka masyarakat akan diperlakukan sesuai dengan hak dan kewajibannya pada pemerintahan desa dinas, begitu 
pula seBaliknya jika berkaitan dengan desa adat maka hak dan kewajiban akan disesuaikan dengan posisi pada desa adat yaitu berdasarkan urutan perkawinan. Seperti yang dikatakan bapak Yudiana selaku Kepala Desa di Desa Tenganan, ketika ada hal yang berkaitan dengan desa dinas pak Yudiana akan melakukan kewajibannya dan mendapatkan haknya sebagai kepala desa, dan ketika ada urusan yang berkaitan dengan desa adat pak Yudianabukanlah kepala desa lagi posisinya di desa adat sesuai dengan urutan perkawinannya yang ke 21 dan beliau akan melaksanakan tugas sesuai dengan jabatannya di desa adat. Jadi disini jelas bahwa pemerintahan desa adat dan desa dinas tidak boleh dipadukan atau saling mempengaruhi.

Sebagaimana diketahui bahwa desa adat dan desa dinas memiliki cara penyelenggaraan pemerintahan tersendiri maka pengelolaan keuangan antara desa dinas dan desa adat juga memiliki peraturannya masing-masing yang dapat dibandingkan sebagai berikut:

a. Dasar Hukum.

Pemerintahan Desa Dinas Tenganan dijalankan adas dasar Undang-undang ataupun peraturan pemerintah yang berlaku. Undang-Undang atau peraturan pemerintah yang mengatur tentang Pengelolaan Keuangan Desa diantaranya (1) Undang-Undang Nomor 6 Tahun 2014 tentang Desa,(2) Peraturan Pemerintah Nomor 43 Tahun 2014 tentang Peraturan Pelaksanaan Undang-Undang Nomor 6 Tahun 2014 tentang Desa, (3) Peraturan Pemerintah Nomor 60 Tahun 2014 tentang Dana Desa yang Bersumber dari Anggaran Pendapatan dan Belanja Negara. Undang-Undang dan Peraturan Pemerintah diatas kemuadin mendasari terbentuknya Peraturan Menteri Dalam Negeri Nomor 113 tahun 2014 tentang Pengelolaan Keuangan Desa. Yang berisi tentang Ketentuan umum, Asas Pengelolaan keuangan Desa, Kekuasaan Pengelolaan Keuangan Desa, APBDes, Pengelolaan, Pembinaan serta Pengawasan.

Sedangkan Pemerintahan di Desa Adat Tenganan dilaksanakan berdasarkan Awig-Awig yang berlaku di desa Tenganan. setiap desa memiliki awig-awig tersendiri. Masyarakat Desa Adat Tenganan menyebut awig-awig yang ada sebagai buku sakti yang sangat ditaati dan dihormati warga masyarakat di desa ini. Ketaatan pada awigawig inilah yang mengakibatkan terjaganya tatanan tradisional kehidupan masyarakat Desa Adat Tenganan. Konon, awig-awig di Desa Tenganan dibuat pada abad XI ,pada awal desa ini didirikan. awig-awig Desa Tenganan tebalnya 58 halaman dan ditulis dalam Bahasa Bali. Namun, pada 1841 masehi terjadi kebakaran yang menghanguskan pekarangan desa, tempat-tempat suci, Bale Agung dan termasuk juga awig-awig. Atas ijin Raja Klungkung saat itu, Raja Karangasem saat itu mempersilahkan warga Tenganan untuk menulis kemBali awig-awig desanya. Dan penulisan awig-awig itu selesai pada 1942 masehi yang kemudian diempurnakan pada tahun 1925, hingga saat ini awig-awig desa tenganan terdiri dari 61 halaman ditulis dengan bahasa Bali.

b. Pihak-Pihak yang terlibat.

Pihak yang terlibat dalam pengelolaan keuangan desa dinas diantaranya :

a) Kepala Desa beserta jajarannya yaitu sebagai pihak yang menyusun APBDes dan mengelola serta mempertanggungjawabkan keuangan desa.

b) Badan Permusyawaratan Desa yaitu pihak yang ikut menyusun APBDes bersama aparat desa lainnya, penyalur aspirasi masyarakat desa serta mengawasi penggunaan dana desa.

c) Masyarakat yaitu sebagai pihak ikut mengawasi bagaimana jalannya pengelolaan keuangan desa dan juga sasaran dari pengelolaan keuangan desa.

d) Pemerintah , merupakan pihak yang memberikan dana kepada pemerintah desa.

Sedangkan Pihak-Pihak yang terlibat di dalam pengelolaan keuangan desa adat diantaranya:

1) Sesepuh, yaitu pihak yang yang memberikan penjelasan mengenai awig-awig dan upacara-upacara atau ritual. 
2) Klian desa yaitu pihak yang menjadi penentu arah kebijakan di dalam pengelolaan keuangan desa yang didasarkan pada awig-awig.

3) Krama Desa , yang merupakan pengelola keuangan desa adat.

4) Masyarakat desa adat, yaitu pihak yang menjadi sumber salah satu keuangan desa adat dan menjai pengawas dari engelolaan keuangan desa adat.

c. Sumber dana.

Sumber dana untuk Desa Dinas Tenganan bersumber dari pendapatan asli desa dan juga dana transfer, Pendapatan asli desa bersumber dari pariwisatanya dan dana transfer dapar bersumber dari bagi hasil pajak, BKK Provinsi, BKK Kabupaten dan juga hibah.

Sedanngkan keuangan atau dana Desa Adat Tenganan bersumber dari bagi hasil dari sesuai sistem Tika. Bapak Yudiana selaku kepala desa menyatakan untuk satu kali panen jika dapat menghasilkan Rp 196.000.000,00 berhubung ada 6 subak dan panen dilakukan 3 kali maka penghasilan desa sebesar Rp 3.528.000.000.

d. Penggunaan Dana.

Keuangan atau dana di Desa Dinas Tenganan dipergunakan untuk pembangunan desa berupa pembangunan fasilitas umum seperti pembelian alat-alat di kantor kepala desa, perbaikan kantor kepala desa, perbaikan ataupun rabat jalan dan juga pembangunan lainnya yang diijinan oleh pemerintah.

Sedangkan dana Desa Adat Tenganan digunakan untuk pembangunan yang tidak diperkenankan menggunakan dana desa dinas seperti pembangunan atau perbaikan tempat suci dan pembangunan bale banjar dan bale agung. Selain itu dana ini juga digunakan untuk pelaksanaan upacara dan tradisi di Desa Tenganan mengingat di Desa Tenganan hampir setia bulan ada upacara agama dan juga akan ada tradisi Perang Pandan yang memerlukan dana yang cukup besar.

e. Pertanggungjawaban.

Desa Dinas Tenganan bertanggunjawab kepada pemerintah yang memberikan dana dalam bentuk LPJM Des. Melalui laporan ini pemerintah dea adat akan menyampaikan bagaimana pelaksanaan dari APBDes. Laporan pertanggungjawaban ini dilaporkan kepada pemerintah pada akhir tahun. Sementara Desa Adat Tenganan bertanggungjawab kepada masyarakat. Setiap tanggal 9 akan diadakan rapat umum di Bale Agung dan disana akan disampaikan apa yang perlu disampaikan dan apa yang ingin diketahui masyarakat. Dan jika ada yang kurang jelas dan harus disampaikan sebelum tanggal 9 maka masyarakat bisa datangke bale agug jam setengah 9 malam karena kelian desa akan selalu ada disana pada jam tersebut.

\section{Kesimpulan dan Saran}

Jadi dapat disimpulkan bahwa, Desa Tenganan merupakan salah satu desa Bali Aga yang ada di Bali. Sebagai desa Bali Aga desa tenganan memiliki tatanan kehidupan masyarakat yang masih sangat tradisional. Pemerintahan di Desa Tengan dibagi ke dalam Desa Ada dan Desa Dinas. Pemerintahan di desa dinas Tenganan didasarkan atas UndangUndang yang berlaku dan pemerintahan desa adat tenganan berdasarkan atas awig-awig yang berlaku. Pemeritahan desa adat harus dipisahkan dari desa dinas. Jika dilihat dari desa dinas tidak ada yang berbeda antara praktik akuntansi dari Desa Tenganan dengan desa lainnya, Namun jika ditijau dari aspek adat maka Desa Tenganan memiliki perbedaan dalam hal Pengelolaan Aset Desa. Pengelolaan Aset di desa Tenganan didasarka pada awig -awig yang ada yang berlandaskan Konsep Tri Hita Karana. Aset utama dari Desa Tenganan berupa Tanah dan tanah desa adat di Tenganan dikelola dengan sistem Tika.

Terdapat saran bagi penulis diharapkan agar dapat membuat tulisan atau ulasan yang lebih baik lagi kedepannya dengan menambah wawasan dan pengetahuan tentang materi yang akan dibahas dan penulisan laporan yang lebih baik. Bagi pembaca, diharapkan melalui laporan ini pembaca diharapkan dapat menangkap bagaimana pengaruh positif dari budaya, tradisi serta filsafah yang diwariskan oleh para leluhur sehingga pembaca seharusnya sadar untuk melestarikan budaya ataupun filsafah yang dimiliki termasuk juga Tri Hita Karana. Bagi pemerintah diharapkan mau mendukung dan menjaga budaya yang 
ada saat ini agar tidak punah tertelan oleh modernisasi dan juga mengembangkan budaya yang ada untuk pariwisata.

\section{DAFTAR PUSTAKA}

Definisi dan Pengertian Kebudayaan menurut Para Ahli. dalam www.lahiya.com diakses tanggal 13 desember 2016.

Menyelami Adat dan Kebudayaan Masyarakat Bali.dalam Bali.panduanwisata.id diakses tangal 13 desemer 2016.

Sudantra.2011,Adat dan Budaya Bali. dalam sudantra.blogspot.co.id diakses tanggal 26 Desember 2016.

Setyadi, doddy. 2015. Pedoman Asistensi Akuntansi Keuangan Desa, diunduh tanggal tanggal 26 Desember 2016, tempdata.iaiglobal.or.id.

Suryaden.2015.Permendagri 113 tahun 2014 Pengelolaan Keuangan Desa. dalam Https;//www.jogloabang.com

Wikipedia.2015.Desa Tenganan .dalam Https:// id.wikipedia.org diakses tanggal 18 November 2016.

Wikipedia.2016.Pengertian Kebudayaan. dalam Https:// id.wikipedia.org diakses tanggal 13 Desember 2016. 